OPEN ACCESS

Edited by:

Michael Shevlin,

Trinity College Dublin, Ireland

Reviewed by:

Mhairi Catherine Beaton, Leeds Beckett University, United Kingdom Catarina Rodrigues Grande, University of Porto, Portugal

*Correspondence:

Dagmar Sedláčková dagmar.sedlackova01@upol.cz

Specialty section:

This article was submitted to Special Educational Needs, a section of the journal Frontiers in Education

Received: 22 October 2021 Accepted: 22 December 2021 Published: 02 February 2022

Citation: Sedláčková D and Kantor J (2022) Lived Experiences of Learners With Cerebral Palsy Educated in Inclusive Classrooms in the Czech Republic. Front. Educ. 6:800244. doi: 10.3389/feduc.2021.800244

\section{Lived Experiences of Learners With Cerebral Palsy Educated in Inclusive Classrooms in the Czech Republic}

\author{
Dagmar Sedláčková ${ }^{1,2 *}$ and Jiři Kantor ${ }^{1,2}$ \\ ${ }^{1}$ Center of Evidence-Based Education and Arts Therapies: A JBI Affiliated Group, Faculty of Education, Palacky University \\ Olomouc, Olomouc, Czech Republic, ${ }^{2}$ Institute of Special Education Studies, Faculty of Education, Palacky University Olomouc, \\ Olomouc, Czech Republic
}

Changes in legislation in the Czech Republic in 2016 moved the system of education towards inclusion and created more favorable conditions for joint education, but we still do not have enough information about experiences of learners with cerebral palsy educated in an inclusive environment. A qualitative design was chosen to explore the lived experiences of Czech learners with cerebral palsy educated in inclusive schools. Semi-structured interviews combined with biographical narration of learners with cerebral palsy, aged 12-20, and a brief questionnaire for demographic data were used for data collection. Data analyses were carried out according to van Manen's approach, including defining the main themes and description of the lived experiences of learners. The following four themes were identified: 1) barriers, 2) strategies for overcoming obstacles, 3) values in relation to peers, 4) and the future. The results of this qualitative study point to a number of obstacles and pressures that these learners face in their education, as well as to the ways of solving some problems. The results indicate that it is important to realize that the consequences of interpersonal relationships significantly influence the formation of self-concept and personality development of these learners, and therefore it is necessary for teaching staff to deal with the support of positive relationships at schools. When creating a supportive inclusive environment, it is also necessary to pay attention to the learners' future, because the present Czech society does not offer sufficiently inclusive conditions in further education and occupation.

Keywords: inclusive education, learners, special educational needs (SEN), cerebral palsy, experience

\section{INTRODUCTION}

Education in the Czech Republic has undergone many changes since 1990s. It concerned mainly the effort for gradual transition from segregated education of pupils with SEN (special educational needs) to joint education of all. The first step in the transition process began with supporting integration of learners with SEN, which was enshrined in the new Education Act (No. 561/2004 Sb.) and was followed by gradual move to inclusive education in 2016 by the Amendment to the Education Act (No. 82/2015 Sb.). These two documents became a milestone for the transformation of the Czech educational system towards inclusive education. The amended School Act (561/2004 Sb.) stipulates the conditions for education of all learners on equal basis and introduces the system of support measures necessary for education of learners with SEN and other details. The support measures include for example use of teaching assistants, individual educational plans, modification 
of required outcomes and evaluation, use of special teaching methods, the forms of education and special aids. A gradual increase in the number of pupils with SEN, especially with physical disability, preferring inclusive education over special education, has been recorded in recent years (Watier, 2016). The transformation has brought to learners with SEN, as well as to stakeholders, several new experiences that have not been examined so far. This development has brought a number of changes. Based on the experiences from other countries, these changes may have resulted in higher chances for development of social relationships (Cologon, 2020; Hasan and Islam, 2020; Rachmadani et al., 2021), higher participation in mainstream environment, and academic gains (Grove and Fisher, 1999; Llabrés et al., 2019; Morelle and Tabane, 2019; Hasan and Islam, 2020) but also in increased confrontation with multiple barriers (Kluth et al., 2007; Forteza et al., 2019; Hasan and Islam, 2020; Rachmadani et al., 2021). In order to optimize the further development of educational practice and school legislation, it is necessary to examine the effects of the transition to inclusive educational policy, and to find out what the needs of pupils with special needs and their families are (Burke and Sandman, 2015). This is true especially for learners who are easily vulnerable and whose participation in education can be complicated by many different barriers. One of these groups are learners with cerebral palsy.

In the medical literature, cerebral palsy $(\mathrm{CP})$ is defined as "a group of permanent disorders of movement and posture causing reduced activities that are attributed to non-progressive damage to the developing brain of a fetus or an infant. Motor disorders of $\mathrm{CP}$ are often accompanied by disorders of perception, cognition, communication and behavior, epilepsy and secondary musculoskeletal problems" (Bax et al., 2005, p. 572). CP is one of the most common childhood disorders (Panteliadis et al., 2015), with a prevalence rate of between 2 and 3.5 per 1,000 live births (Colver et al., 2015). It is also one of the most common examples of physical disabilities that can be found in Czech schools (Vítková, 2006).

Some psychosocial characteristics of learners with $\mathrm{CP}$ associated with manifestations and effects of their disorders have an impact on parents' experiences with their children's education. These experiences are characterized by, among other things, frequent encounters with environmental barriers, either barriers related to architectural accessibility, or barriers in the attitudes of the environment (Krastina et al., 2006; Tran, 2014; De Villiers, 2015; Cologon, 2020 and others). CP is an example of obvious disabilities, which is, in most cases, pointed out by appropriate compensatory aids and the aesthetic appearance of the pupil, especially in pupils with a more severe degree of functional impairment. The social environment of these pupils tends to be protective, which may reduce the pupil's independence and autonomy (Hasan and Islam, 2020). Similarly, the relationship between parents and their children with a more severe degree of physical disability is often characterized by a high degree of fixation (Svoboda et al., 2015), which can persist into adulthood. Of course, parents' worries about their child also play a role, as they may not be able to defend their rights sufficiently and are much more often the targets of bullying and other undesirable social manifestations (Cavet, 2000; Lemos, 2016). The physical appearance, communication disorders, and other problems of these learners may also have the effect that other people, including teachers, attribute lower cognitive capacity to these students, which has a negative effect on expected performance (Majerová, 2014).

A study on the analysis of the lived experiences of parents of children with severe multiple disabilities has recently been carried out in the Czech environment (Kantor et al., 2015). Some families in that study had a child diagnosed with CP and all those children were educated in a special educational environment. However, due to the current inclusive direction of the school system, we need to draw conclusions about the pupils with $\mathrm{CP}$, who are in mainstream schools, much more urgently. In most cases, these are children whose physical disability is not combined with more serious disorders of communication or mental functions. These pupils were typically placed in schools for pupils with physical disabilities in the former Czechoslovakia, but after 1989, they began to be increasingly educated in regular classes (Michalík, 2015; Watier, 2016). At present, inclusive education should be the first choice for most pupils with CP and similar types of disabilities. However, inclusive education professionals need to understand the experiences of learners with $\mathrm{CP}$ and their parents in an inclusive education environment more deeply. Based on the previous experience and reflection of pedagogical practice, we believe that many schools are not ready for the education of these students yet. We therefore consider it important that the further development of educational policy and the inclusive practice itself will take sufficient account of the experiences of pupils with SEN and their parents.

\section{METHODS}

In this text, we try to gain a deeper understanding of the experiences of learners with CP educated in an inclusive environment within lower and higher secondary schools. The following research question was identified: What is the experience of learners with cerebral palsy with education in an inclusive educational environment?

A qualitative design was chosen for this research, namely the phenomenologically oriented methodology of van Manen's analysis of lived experience (Van Manen, 1997), which had been used in previous similarly focused studies (eg., Forteza et al., 2019). This method enables a deep understanding of how learners with CP experience inclusion, how inclusion affects their lives and how these learners perceive the positive and negative aspects associated with inclusive education (Van Manen, 1997). The aim of the research was not to understand the experiences of individuals as facts, but to determine the understandable significance of these experiences (Van Manen, 1997). Additionally, it was necessary to think about each experience in a broader context, including recalling, where the experience was reflected after it had taken place or had been experienced (Marshall and Rossman, 2011). We respected the subjectivity of each learner's experience, thus the data were 
evaluated separately for each learner and in the context of their individual lived experience; although we also looked for common and overarching themes across the individual cases.

Before starting the research itself, a literary search of available sources in the Czech Republic and abroad was performed (Sedláčková, 2018a; Sedláčková, 2018b). It was found that similarly focused qualitative research was conducted rather sporadically and the understanding of the pupil's experience with a physical disability in an inclusive environment is relatively superficial (and practically unknown in the home environment). The research was conducted during 2019-2021. The research was approved by the Ethics Committee of the Faculty of Education, Palacký University in Olomouc (doc. no. 6/2019), with respect to the Directive of the Dean of the Faculty of Education UP, 3S/2015. Parents or legal representatives of all participants had previously signed an informed consent as an agreement to the learners' participation in this study, as well as providing data and publishing them, provided that anonymity is respected.

\section{Data Collection}

For data collection, a content analysis of school documentation and materials provided by the learners' parents was used (reports on the participant's health condition, educational outcomes, individual educational plan, support measures, etc.), along with interviews with the parents to supplement information and autobiographically oriented semi-structured interviews with learners (from March 2019 to October 2020). Before the beginning of each interview, the participants and their parents or legal representatives were acquainted with the objectives of the research, its process and the planned outcomes. The interviews were conducted in the form of learners' autobiographical narratives depicting the course of education from the beginning of kindergarten to the current state. At the same time, some thematic areas were emphasized, namely their course of education at primary school/and eventually in the secondary school, overcoming obstacles, the issue of support measures, the family role, their cooperation with institutions, managing school demands, restrictions due to their disability, their participation, the school climate, and their plans for future. The interviews took place at home or school environment of each participant in the length of $40-60 \mathrm{~min}$ and one or two interviews were conducted with each participant. The interviews were recorded on a mobile phone, using the Dictaphone application (version 1.8.0, ALON Software Ltd.) with the written consent of all participants. The participants were left free space for narration, only in the case of necessity, for example, when they were not able to reflect more deeply on their experiences or deviated too much from the topic, some auxiliary topics for conversation and supportive questions were used by the interviewer. The areas focused on the following topics: the course of education from pre-school to the present, the process of adaptation to the school environment and managing school demands, the areas of their support, factors limiting participation in education, the role of family and cooperation with institutions outside of school, happy and sad moments in the school and beyond, the school climate and the issue of their future. All the conversations took place in a friendly atmosphere.

\section{Data Analyses}

The process of data analysis began with a verbatim transcription of the recordings of the interviews into the program Pages (for the sake of clarity, at least in some places, the statements quoted in the following chapter were slightly stripped of speech incomprehensibilities and sensitively modified without interference to the meaning and character of the message). The data obtained from the interviews were subsequently analyzed in six phases using the van Manen's approach (1997):

- "Turning to the nature of lived experience"-a part of this phase is the formulation of the research question.

- "Exploring the lived experience"-it represents the deepening of knowledge about the subject's experience through the application of in-depth interviews.

- "Reflecting on important themes that characterize researched phenomenon"-it represents the process of thematic analysis with emphasis on the process and identification of key topics for the phenomenon.

- "Describing the researched phenomenon by the art of writing and retelling"-its aim is to make visible the thoughts, feelings, and attitudes of the research participants.

- "Keeping strong and transparent relation to the studied phenomenon"-it represents maintaining a focus on the research question.

- "Balancing research context by thinking about both the whole context and its parts"-it assumes a consideration of the ratio of the overall results to the importance played by the individual parts in the overall structure (Van Manen, 1997).

Van Manen's analysis allows the process to respond flexibly to the emerging data and topics, so that it is not necessary to follow exactly the order of the individual steps during it, and you can go back or move forward, as needed. The procedure included a thematic analysis to record the topics in the data set (Braun and Clarke, 2006). The topics are a set of ideas that are related to the research question and appear repeatedly in the text (Braun and Clarke, 2006). To define them, three steps of thematic analysis, according to Van Manen (2016), were used: a detailed reading of the text, an explanatory approach and a holistic approach. The texts were repeatedly read with an effort to answer the question of what the read sentence or the part of the text reveals about the studied phenomenon. The keywords (codes) were defined, and the statements related to them were marked. Based on the codes, the second phase of the thematic analysis took place, with an effort to find out which statements best described the nature of the studied phenomenon. This step made it possible to link similar passages under narrower sub-themes, and also broader themes, which captured the overall impression of the 
conversation. During the analysis, the thematic base gradually expanded with a growing number of emerging themes and subthemes.

The individual thematic analysis was first performed for each participant separately, and only after the analysis of each case was completed, we compared and looked for the themes and subthemes that go beyond the individual cases (so-called overarching themes). In the text, the themes are supplemented by illustrative statements of the participants and by the table informing about presenting the presence of defined themes and sub-themes in individual learners (Table 1).

\section{The Characteristics of the Research Sample}

The inclusive criteria of participants in the research sample:

- The learner has a diagnosis of CP, is in the age range 12-20, and is without the presence of intellectual disability or severe sensory disability.

- The learner is educated at higher or lower secondary schools.

- The learner has at least 2 years of experience with inclusive education.

- The learner is capable of sufficient self-reflection necessary for data collection using in-depth interviews.

Intentional selection was used to create the research sample (Gavora, 2000). Learners were contacted via the schools where they were educated at that time, and by telephone or e-mail communication with their parents. The intention and the course of the research were briefly described to them in advance. The informed consent was signed by the parent before the interview in all the cases. Whereas the phenomenological methodology does not require large samples and more important than the sample size is in-depth inside in participants' experiences, in total, only three learners with CP (hereinafter referred to as codes T1, A2, J3) participated in the research. An overview of participants with brief characteristics is given in Table 2 .

Learners with $\mathrm{CP}$ had problems, especially in the area of movement, caused by limited mobility of both lower limbs. All learners can move in an orthopedic wheelchair at school, while the student J3 can also walk with crutches for a short distance, but at school it limits her independence. Learners A2 and J3 also have limited mobility of the upper limbs, which causes difficulties in painting, drawing and other physically oriented activities. J3 has difficulty synchronizing the movements of her right and left upper limbs. A2 and J3 also have visual impairment, which they partially compensate by dioptric correction using glasses. All three learners have a rich vocabulary and excellent expression skills, they are very communicative and have good or very good academic results. Learners T1 and A2 do not participate in the lessons of physical education. All three learners have a teaching assistant and other support measures (SM) given by their individual educational plan (individual curriculum). The parents of all three girls cooperate with the school counseling facility. All participating learners are educated in an inclusive school, while the pupil $\mathrm{T} 1$ is educated in an inclusive Waldorf-type school and the pupil J3 has already experience with both primary and secondary education.

\section{RESEARCH RESULTS}

Based on the analyses of the interviews with learners with $\mathrm{CP}$, the following five themes were identified-1) barriers, 2) strategies for overcoming obstacles, 3) different values compared to peers, 4) the future and 5) peer relationship. Sub-themes were defined within each theme (19 sub-themes in the case of the pupil T1, 26 in A2 and 28 in J3), then sub-themes related to similar issues were for clarity merged into the resulting 20 sub-themes, which are summarized in Table 1.

\section{Barriers}

The learners described various barriers in education. Architectural barriers in schools and the absence of barrierfree access to schools were a problem. Also, in some cases, parking spaces were not provided near the school entrance, where the parents could stop safely with a car and unload or load their child. For T1, the problem was related to prohibited entry to the schoolyard, with the principal refusing to grant the parents an exception and to deal with the matter. For this reason, parents of T1 had to walk with their daughter around the entire grounds. J3 also mentioned an insufficient selection of barrierfree schools. Out of the total number of fifteen secondary schools (three of them are grammar schools), only one was considered barrier-free in the district town near to which J3 lives.

All learners had, to varying degrees, some negative experience with difficulties with teachers, as well as with some employees of some organizations that cooperated with the school. Among the characteristics of teachers that the learners find difficult to educate them well are lack of empathy, unwillingness to get into the role of the person in a wheelchair, unwillingness to understand their needs and to make an effort to help them, to facilitate their education and to enable them to do the activities that normally the others do. It is often the attitudes of the teachers that are the main reasons for limited participation of learners with $\mathrm{CP}$, as it leads to exclusion from both school and extracurricular activities. This also happens in cases where an easy solution would allow their participation. J3 commented on the principal's reluctance to support teachers in the in-service training, which would enable her to take part in ski training, which she was interested in: "I'm not the last person in a wheelchair at the school, am I? I don't understand it." She also talked about the behavior of a teacher on Paralympic Day, who was the only one who refused to sit in an orthopedic wheelchair. Instead, she left the classroom and left the students without any competent supervision.

Learners A2 and J3 pointed out that teachers did not comply with the support measures set out in their individual curriculum (IC). The learner A2 said that some teachers not only bother to work according to her IC, but they also express their negative attitude by their behavior: "It would be necessary for one half of the teachers to start teaching according to my curriculum... simply so that those two completely bad teachers might start 
TABLE 1| The overview of categories, themes and sub-themes.

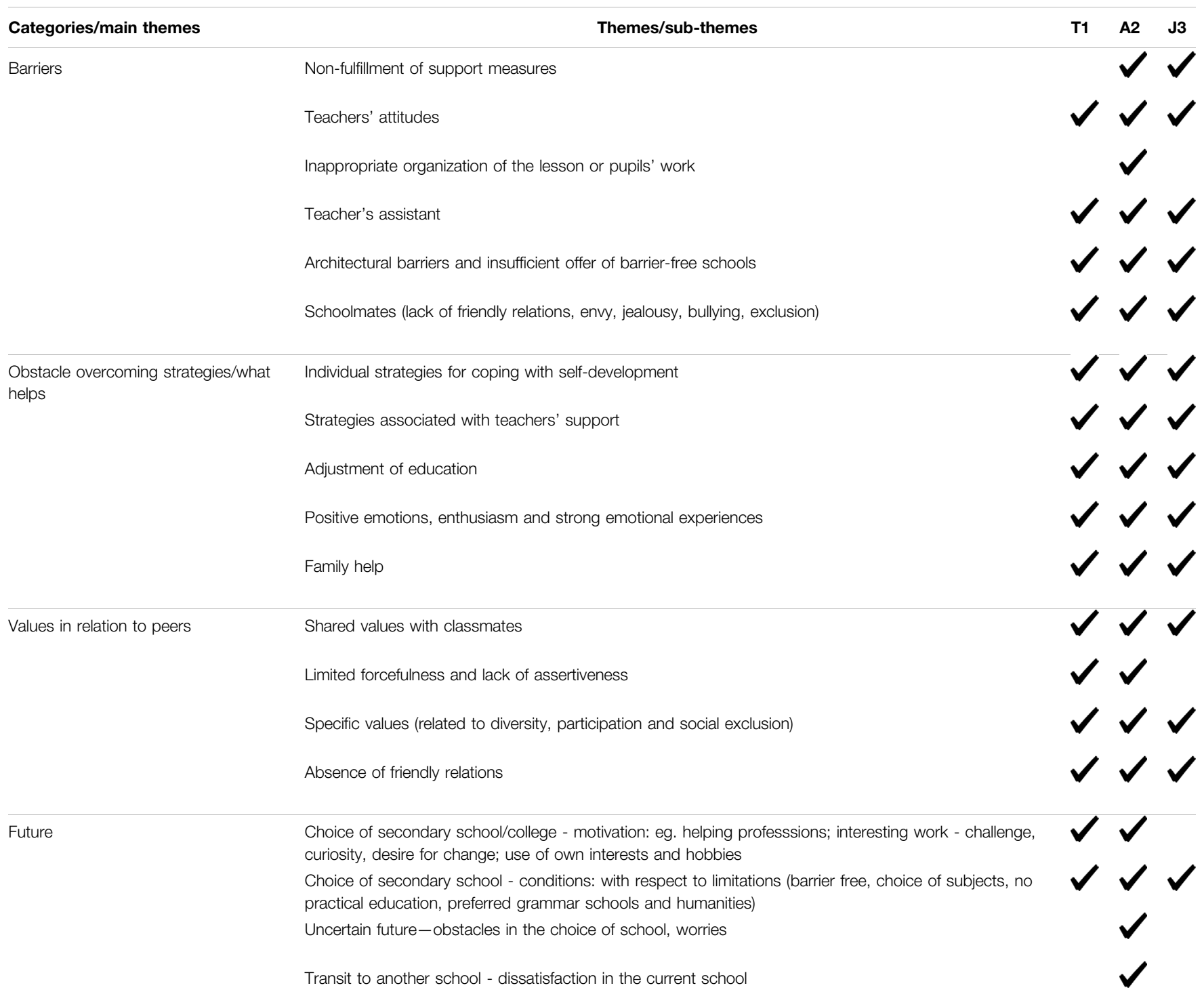

behaving normally and wouldn't be so biased against me. When, for example, the teacher gives me the "individual" (individual work), and gives me a task, for instance, she says about me that I should do it differently, but she says it in a way as though there was something stupid about it, as if it bothered her." (A2) J3 pointed out that perhaps no one at school had read her individual curriculum for physical education lessons. According to A2, the fact that the learners have a physical disability is even reflected in her worse evaluation: "And the teacher, he teaches me physics, he, for example, graded my tests on physics every time D, really every time. Even though I wrote according to the textbook, I'm sure about it." In connection with meeting SEN of the pupils with physical disabilities and providing necessary school aids, the pupils also complained about the limited material equipment, although schools receive increased financial support for learners with physical disabilities in the Czech Republic. These problems were associated, for example, with copying textbooks or the lack of facilities for rest.

Problems in education can also be related to teachers' lack of experience in the issue of learners' special needs. This was one of the reasons why the learner A2 felt segregated in the classroom among specific examples of situations, she mentioned working in pairs or small groups: "Well, this is what I really don't like doing, because... we form pairs ourselves or, in this case of the better teachers, the teacher divides us herself; probably because, now it may sound silly, but probably because of me, because she knows that I just can't find anyone to work with me." (A2).

The education of learners A2 and J3 was repeatedly accompanied by problems with the teacher's assistant. Either she was an inexperienced assistant, an assistant whose state of health or physical condition did not meet the needs for handling a person with $\mathrm{PD}$, or she lacked some necessary character traits or qualities. A2 had a negative experience with the reluctance 
TABLE 2 | The research participants.

\begin{tabular}{|c|c|c|c|c|}
\hline \multicolumn{5}{|l|}{ Learners with CP } \\
\hline $\begin{array}{l}\text { A learner with CP: } \\
\text { sex, pseudonym, } \\
\text { code, age at } \\
\text { the time of } \\
\text { the interview }\end{array}$ & $\begin{array}{l}\text { Siblings: Sex, age, } \\
\text { SEN, school, family } \\
\text { background }\end{array}$ & $\begin{array}{l}\text { Type of school } \\
\text { at the time } \\
\text { of the interview }\end{array}$ & Type of disability & $\begin{array}{c}\text { Functional } \\
\text { capabilities/support measures }\end{array}$ \\
\hline \multirow[t]{2}{*}{ female, Táňa, T1, 16} & - no siblings & $\begin{array}{l}\text { - a lower secondary } \\
\text { school, 9th class } \\
\text { (last year - 9th) }\end{array}$ & CP (spastic diparesis) & $\begin{array}{l}\text { - wheelchair movement; everyday } \\
\text { wearing glasses }\end{array}$ \\
\hline & - a complete family & & & $\begin{array}{l}\text { - SM: release from PE; lessons of special } \\
\text { support; teacher's assistant; copying } \\
\text { of materials and texts; time increase }\end{array}$ \\
\hline \multirow[t]{2}{*}{$\begin{array}{l}\text { female, Alenka, } \\
\text { A2, } 16\end{array}$} & $\begin{array}{l}\text { - brother, 11, no SEN, elementary school } \\
\text { - sister (twin) - died in early childhood }\end{array}$ & $\begin{array}{l}\text { lower secondary } \\
\text { school (8th year) }\end{array}$ & $\begin{array}{l}\text { CP (spastic diparesis with } \\
\text { left hemiparesis; visual } \\
\text { impairment) }\end{array}$ & $\begin{array}{l}\text { - wheelchair movement; everyday } \\
\text { wearing glasses } \\
\text { - SM: release from PE; lessons of special } \\
\text { support; teacher's assistant; copying } \\
\text { of materials and texts; time increase; } \\
\text { edited curriculum in M, P; verbal } \\
\text { evaluation in M, P and C }\end{array}$ \\
\hline & - divorced family, shared custody & & & \\
\hline female, Jitka, J3, 20 & $\begin{array}{l}\text { - sister (twin), 20, congenital } \\
\text { malformation - spontaneous intestinal perforation } \\
\text { (newborn perforation of the colon) - surgery - }\end{array}$ & $\begin{array}{l}\text { grammar school, } 4 \text { th } \\
\text { year }\end{array}$ & $\begin{array}{l}\text { CP (spastic diparesis with } \\
\text { left hemiparesis; visual } \\
\text { impairment) }\end{array}$ & $\begin{array}{l}\text { - wheelchair movement; daily wearing } \\
\text { glasses }\end{array}$ \\
\hline
\end{tabular}
complete healing at about 6-7 years of age; visual impairment; dyscalculia and slow pace of learning; grammar school - 4th year

- compete family

\begin{abstract}
- SM: teacher's assistant; copying of materials and texts; edited curriculum in $\mathrm{PE}$ and $\mathrm{M}$
\end{abstract}

CP - cerebral palsy, SEN - special educational needs, $M$ - mathematics, P-physics, PE - physical education, C-chemistry, SM - support measures.

of the current assistant, and with feelings closely related to intimacy, feelings of shame and embarrassment in front of schoolmates due to inappropriate approach of the assistant in the past: “...my worst memory was probably that ...I'm very ashamed of it, how shall I say it. . plainly, once I didn't get to the toilet in time and the assistant...how to say it...she smeared it on my clothes..." For the student $\mathrm{T} 1$, the problem was mainly a strong fixation on the assistants that she was satisfied with, and consequently the troubles in adapting after the assignment of a new teaching assistant: "The worst day was probably when I was informed that my assistant would leave to study at university and that I would get another one..." (T1).

Barriers in the educational environment can be related not only to teachers, but also to the behavior of classmates and to relationships with them. The learner A2 tries to avoid performing together or doing group work: "Well, because it's completely useless to sit there, in a stuffy, crowded room, and to wait for the moment I shall wave a fork twice and then wave once again over the whole curtain we play a shadow theatre. And that's just to make everyone swear at me for ruining it. The whole class, the whole team, the classmates. It was the same last time, but I didn't do anything wrong, at least I think so. They always blame me for something, accuse me of spoiling it, doing it wrong, ruining it." (A2). When she was asked how she got on with her peers, she answered: "Badly, badly, badly. Well, it's in the flow of time, because in the first, second and third class, they were still all very nice, we all made friends with each other, but then in the fourth and fifth class they started to bully me a bit and from the fifth class, actually, up to now, until eighth class, they haven't noticed me. . . Well, by the way, the behavior of that class is completely pathetic, I don't fit into that class at all." The position of A2 in her class team influences her overall attitude towards the school and collective activities.

On the other hand, J3 mentioned situations where her classmates envied her the benefits associated with her special needs. Some classmates ignored her or avoided her: "Well, some of them were without problems and some were more like avoiding me. And some might still be envious that I could leave for lunch five or so minutes earlier. I didn't have any friends there, either at elementary or at secondary school. To tell the truth, we don't see each other, and there were more those envious ones (schoolmates)." (J3).

\section{Strategies for Overcoming Obstacles}

The theme 'strategies for overcoming obstacles' includes statements about everything which was beneficial in education of learners with CP. Positive emotions, enthusiasm and strong emotional experiences associated with learning, extracurricular activities or sharing interests and activities with classmates also help learners with SEN to overcome obstacles. These experiences strengthen their self-confidence, help to strengthen their position in the team and to create a positive attitude to the school. In the case of $\mathrm{A} 2$, the positive emotions were related to feelings of happiness and satisfaction thanks to the help of classmates, and peers' interest in her person. Learners $\mathrm{T} 1$ and $\mathrm{J} 3$ had positive 
experiences from school lessons and extracurricular events, such as a ski course, trips, the "Day of emergency simulations," etc. In addition, learners $\mathrm{T} 1$ and $\mathrm{J} 3$ developed a number of their own defense strategies that help them to overcome feelings of disappointment and sadness. It has helped them to take things as they are, to learn not to worry about the opinions of others and to come to terms with an unfavorable situation, to try to understand the unfavorable actions of others and to increase their own efforts to achieve what matters. The learner A2, on the other hand, has gradually lost interest in activities that reduced her self-confidence, and after repeated negative experiences, she has resigned and decided on a radical solution - to hopefully go to another type of school.

Strategies associated with teachers' support include, above all, the humanity and helpfulness of school and teacher management, a friendly approach to learners, an effort to organize teaching so that no one is excluded, and the natural respect that teachers can gain in the classroom to ensure a good classroom atmosphere. "... there was still Mr. (name of the previous director). He was more like a human, or something, he simply understood, he could take it in." (J3). The learners also appreciate any support that enabled them to increase the level of their participation in various school activities. The learner T2, for example, managed to participate in ski training after previous failures, which was one of her strongest experiences: "Well, it was great. That could be repeated, it was really great. We were there for about 5 days, it was the first time on a monoski, and it actually helped me.... in fact, I had an assistant from the [university's] Faculty of Physical Education, and she helped me with that. And the kids were nice there too. That was probably the best experience ever here at school." (T1).

For all learners, the adjustment of education was essential, provided that these specifics of education are respected by the teachers. These adjustments concerned the support measures, like the assignment of a teaching assistant, modifications of the content of the curriculum in the subjects in which the pupil's disability restricts the learner's performance or quality of work, release from certain subjects and replacement of these lessons by special pedagogical care subjects and assessment adjustments. All three learners stated several times how important for them the help and support of their parents or family is, especially mothers, but also fathers or siblings. In the case of the student J3, her sister of the same age, with whom she has attended school from kindergarten to the last year of the grammar school, has helped her to compensate the absence of friendly peer relations. Her sister has been a link between J3 and the class, so even after a long absence due to the medical procedures and convalescence, J3 did not have much difficulty acclimatizing and rejoining the class quickly.

\section{Values in Relation to Peers}

During the interviews, some values that learners probably share with other classmates and that relate to relationships with teachers emerged. T1 says about her teacher: "... our teacher is nice, even in teaching. He can teach very well, and we have him now as a class-teacher too, and that's what I've always wanted, and now it's finally come true, at least for one school year." (T1).
On the other hand, the value system of these learners is largely related to the needs that are associated with their health and functional limitations, their possibility of participation and unmet needs in relation to peers. Learners often appreciate what their peers take for granted, such as the greater autonomy and independence that an orthopedic wheelchair has made possible: "Well, I was really glad to have the wheelchair, that I didn't have to chase the assistant all the time. That I could store all my things there and move, I didn't need anyone to help. But then the assistant came to the class again and I sat down on the chair, and she took the wheelchair from me-it's just some details, but ... It's details, yes, but essential?" (J3).

Learners T1 and A2 struggled with having limited forcefulness and a lack of assertiveness, which often, beforehand, deprived them of shared experiences with the class or of the opportunity to defend themselves against unfair or inappropriate behavior of the environment. The learner A2 is very appreciative of the social support that helped her in these situations: "I had two most beautiful school experiences. The first one was in the lesson of arts, I just had to cut something and everyone in the class started to laugh at me that I made "puzzles" of that, although I didn't do it on purpose, of course. And one boy stood up for me in front of the whole class then, that was really nice, yeah. And then another one like that-I was probably the most impressed by the fact that once, we'd just left the classroom and the boy behind me asked me to stop and he started doing me something behind my back and then he said "good, you can go," and finally it turned out from that that he'd actually fixed the handlebars on my old wheelchair. So those are about two single memories, beautiful, yeah." (A2) Friendship and class relationships are extremely important to A2. In her current school, however, it is difficult to satisfy her need for belonging to the group of peers due to repeated failures in peer relationships, disappointment from comparing herself to her healthy classmates, to their appearance, behavior, and abilities. All this has distracted her from the team of classmates and has led to feelings of insignificance, loneliness, invisibility and sadness: "...when I say I don't fit among them, among the girls mainly, because I don't fit among the girls, as they are just somewhere completely different than me. They think they're so great, I can give some examples: they still spin on one leg, like some ballerinas, and they show off with their great hairstyles, dyed hair, great colored braces and whatever else, and I just feel next to them like ... like nothing. Well, I'm like invisible, you know." (A2) A2 is jealous of her healthy girl-classmates and envies them, the way they attract the attention of the class. She also states that they have no interests in common, which has been making even greater distance between her and other classmates in recent years, as she has been getting older.

It was clear from the interviews that the absence of friendly relations was evident in all learners in the normal educational environment. Pupil T1 prefers friendly relations with similarly handicapped peers. She said that she had a classmate at school, with whom she had been sitting in the same desk for several years, but they were not in contact outside school. She considered a pupil with a similar disability, a few years younger, who attended the same school and also used an orthopedic wheelchair to move, as her friend. 


\section{Future}

The theme of the future was related mainly to the choice of a secondary school or university and their future profession. None of the girls talked about any plans for their personal life. When considering further education, all students had to deal with the limitations associated with their disability. They were looking for a school that is barrier-free, where there was not included much practice lessons and which was not limited by the taught languages. Learners $\mathrm{T} 1$ and J3 managed to find such a school and both of them were informed at the time of the interview that they had already been accepted there. A great motive associated with the transition to a new school in all pupils was a desire for change. They chose the study field according to their own preferences and were looking forward to entering a new school facility. On the contrary, the learner A2 had concerns associated with her idea of an uncertain future and obstacles connected to the choice. Due to her disability, this student is unable to succeed in most of the professions that she could study in mainstream apprenticeships and at secondary schools. Her academic results are very good in some subjects, especially in the humanities, but she fears that shortcomings in mathematics will prevent her from being admitted to a grammar school or secondary school with an economic focus of the study. Similarly, schools where manual skills or physical fitness are required for the study field are not suitable for her due to her limited mobility.

In addition, at the time of the interview, the learner A2 was looking forward to the transit to a special school for learners with physical disabilities, due to increasing difficulties in relationships with peers and with some teachers: "One more month (until the end of the school year and then to entering the special school) ... I just can't stand it here (at the current school) anymore." (A2). “... but it doesn't matter, because it ends there. I will go to... (the name of the special school and the city where it is located) from September. I look forward. I've already been there to see it and I know my new classmates and roommates only at first glance, we've met just once, but otherwise I don't know them. But I'm looking forward to it, it will be different there ..." (A2).

\section{DISCUSSION}

Four main themes were identified in this study: 1) Barriers, 2) Strategies for overcoming obstacles/what helps, 3) Values in relation to peers and 4) Future. The first theme includes architectural barriers that are typical for learners with physical disability in the Czech republic as well as in other countries (Filipová, 2002; Habart, 2010; Tran, 2014). This issue does not deal only with the limitations in barrier-free access to school buildings, but also with access to individual floors and rooms, like classrooms and all school facilities. The number of barrier-free schools in the Czech Republic is still quite low, mainly because most schools are located in old multi-story buildings and their rebuilding is expensive. The choice of barrier-free secondary schools is even lower than in the case of elementary ones. The other four sub-themes were associated with teaching staff. Inappropriate approaches of teachers and teacher's assistants were related to their opinions, attitudes, personality traits, expertise and the methodology of their work. Similar deficiencies were described in some foreign studies (Tran 2014; De Villiers, 2015; Hasan and Islam, 2020; Khairuddin and Miles, 2020). Such attitudes in this study are also connected with unmet educational needs of learners with $\mathrm{CP}$ and disrespect for their support measures. Another barrier was concerned with schoolmates, namely with the lack of friendly relations, but also with envy, jealousy, or even bullying and a tendency towards exclusion-the challenges that were also described in some previous studies (Kluth et al., 2007; Rogers, 2007; Cook et al., 2016; Cologon, 2020). It is worth mentioning the reasons related to the problems in relationships with peers, such as an inexperienced teacher unable to provide discipline and a positive climate in the class or differences in interests of classmates and their mutual comparison.

In connection with the barriers, there also emerged themes associated with strategies of overcoming them. The help of parents and their active participation in the educational process of their children is one of the generally recognized strategies (Grove and Fisher, 1999; Lilley, 2014; Morelle and Tabane, 2019) and works well for learners with CP. Parents are the link between the school, their children with CP and the professionals in health care, they stand as the source of information, as well as advisers, advocates, assistants and helpers. Ryndak et al. (2014) state strategies and features like assertiveness, optimism and other strengths that are necessary for parents to overcome obstacles when educating their children with severe disabilities. This study similarly points to such necessary strengths and coping strategies, but in the case of the learners themselves. Optimism, assertiveness and positive emotions, enthusiasm and strong emotional experiences associated with education were very helpful in creating healthy self-confidence and consolidating their position in the collective of peers according to the narratives of some participants in this study.

Learners with CP are limited in many aspects of everyday life in comparison to their healthy peers and this affects their attitudes and value systems, which is reflected also in the educational process. Some values are shared with their healthy schoolmates and are typical for a specific age group, like experiencing positive feelings associated with hobbies and free time activities, school success, full participation, sharing experiences in communication with peers, etc. (Rokeach, 1973; Vágnerová, 2000; Sak and Saková, 2004). Other values that emerged from the interviews in this study are specific for learners with $\mathrm{CP}$ and reflect restrictions imposed on them by their disability. These learners' values are often connected with their negative experiences, lack of participation in common activities and also the solitude of these teenagers. It is not an exception that some of these learners value the slightest expression of interest or affection on the part of their peers (Gray, 2005). According to other authors (Forteza et al., 2019; Hasan and Islam, 2020) the absence of friendly relations and their loneliness can have a negative impact on their self-concept; it does not support healthy personality development and can lead to limited forcefulness and lack of assertiveness. Consequently, these learners can become even more vulnerable. 
Issues connected to the future is another important theme in this study. It is surprising that none of the participating learners dealt with the issue of their personal life, including independent living, starting a family or motherhood, etc., that is often discussed by parents of learners with SEN (eg., Miller et al., 2018). In all three cases, the learners paid interest mainly to subsequent study and future career. Despite considerable personal motivation, the learners again must reckon with a number of restrictions associated with both physical and social barriers in society. The choice of secondary schools which could be possibly considered is very limited due to functional limitations of learners with $\mathrm{CP}$, as well as due to the limited choice of barrier-free schools (Lederer, 2015). In some cases, there are even fears that the learners will not find any suitable options associated with studies and employment. The theme of future was also connected with leaving the current school and transitioning to a special school; therefore, it must be taken into account that it is beneficial that both possibilities still exist, and it is necessary to enable the transition between them according to the student's needs. As could be seen in this study, inclusive schools in the Czech Republic may impose upon learners with CP multiple restrictions despite the changes in the educational system in recent years. UNESCO (1994) as well as some authors (eg., Krastina et al., 2006; Webster and Roberts, 2020) recommend so that the learners with $\mathrm{CP}$ and their parents should have a choice between education in inclusive or special educational environment, depending on which school is able to provide these learners an adequate necessary support. The qualities and benefits of such multitrack approach are appreciated not only in the Czech Republic, but also in other countries, eg., in the United Kingdom, Denmark or France (Krastina et al., 2006; Sentenac et al., 2013; Webster and Roberts, 2020), and the benefits of such option were also evident in our study, although the trend is moving toward a preference for inclusive education. Special schools remain to be a lifeline especially for some learners with $\mathrm{CP}$ who experience a failure in inclusive environments.

The topics that emerged during the interviews are closely related to the heterogeneity of the educational environment and to the basic values of school inclusion. Heterogeneity in the educational environment is often highlighted as a plus of inclusive pedagogy (Janoško, 2013; Mitchell, 2014; Tesařová et al., 2016), because it enables social learning (Maňák and Švec, 2003; Tesařová et al., 2016; Hasan and Islam, 2020), provides more opportunities for learning for all learners (Wilhelm, et al., 2002), and prepares for the perception of otherness as a fundamental social value (Přibán̆, 1997; Alexander, 2006). However, the heterogeneity of the educational environment has also its downside. In this study, the problems proved to be mainly in connection to comparing learners with $\mathrm{CP}$ to their peers. This was especially the case for the learner A2, whose experience illustrates very well how the difference caused by her disability can be a strong barrier to establishing relationships with peers and the reason for social exclusion. The risk of insufficient meeting psychosocial needs of these pupils begins to grow during adolescence, when many individuals with disabilities begin to prefer a community of people with similar health problems, in which they can share intimate topics, look for a partner (Vágnerová, 2004), etc.

Although the heterogeneity of the educational environment is attributed to the possibility of benefits for all involved, it strongly depends on the quality and nature of the social climate of schools and the attitudes of teachers and classmates towards learners with SEN (Hasan and Islam, 2020). The experiences with inclusive education described in this study take place at a time of a gradual transition toward inclusive education policy, which has not been fully understood and accepted in many Czech schools yet (Bendová and Fialová, 2015; Hronová, 2020). It must be taken into account that the decades of segregation, the dominance of institutional care and the denial of fundamental human rights impacted the attitudes towards people with physical disability and their families in the Czech Republic (Michalík, 2015). These learners were often evaluated on the basis of prejudice, they are attributed intellectual disabilities and their real abilities are often underestimated (Michalík, 2011). Based on our knowledge of actual inclusive practice in the Czech Republic, it can be hypothesized that the current situation of many learners in inclusive settings is not very favorable, even though it has been slowly improving in the recent 2 decades. It can take several decades before a change in the thinking of teachers and society and the philosophy of inclusive education will become accepted as the norm. However, in the current situation, it is very urgent to address the experiences of learners with CP themselves and their parents, who reveal what is important to them, what barriers they face and what strategies they have adopted to overcome those barriers. These experiences can help to educate teachers in practice and to train new generations of teachers at universities. At the same time, they are essential for the creation of legislation and should be taken into account, especially in the production of recommended and methodological procedures issued by the Ministry of Education towards inclusive education (Kantorová and Klugar, 2020).

The conclusions of this study must be dealt with carefully. Although we consider the main themes as typical for students with CP (based on our expertise and experience), the obtained data cannot be generalized to the whole group of learners with $\mathrm{CP}$ that is very diverse and whose needs and individual experiences differ from each other. The obtained results can be assessed only in connection with these cases. It will be needed to monitor how learners with CP experience their education in inclusive environment in future studies, as there are many changes and developments in the educational system in the Czech Republic in recent times.

\section{CONCLUSION}

This qualitative research brought forward important results from three interviews with learners with $\mathrm{CP}$, focused on their experiences with inclusive education. These learners face a number of obstacles and they are under a great and multifaceted pressure, associated not only with learning demands, but also with mutual relationships with peers and teachers, educational conditions complicated by both social and physical barriers, as well as unmet emotional needs. The issue of 
architectural barriers and the limited number of barrier-free schools limits their inclusion. The attitudes of the surroundings, whether they are the teachers, peers or peers' parents, adversely affect their selfconcept, self-esteem and personal development, and limit their ability to become independent in the future. This study provides a deeper understanding of the barriers and issues that students with $\mathrm{CP}$ may encounter in an inclusive environment and that should be of interest to stakeholders. This is particularly important in the countries where the education system has only recently moved towards inclusive practice. We can draw on the experience of other countries, however, more data from the Czech educational environment will be needed to plan effective changes in our education policy, as this group of people with disabilities is poorly studied.

\section{DATA AVAILABILITY STATEMENT}

The raw data supporting the conclusion of this article will be made available by the authors, without undue reservation. However, sensitive information leading to the identification of participants will be excluded.

\section{ETHICS STATEMENT}

The studies involving human participants were reviewed and approved by Ethics Committee of the Faculty of Education, Palacký University in Olomouc, doc. no. 6/2019, approved on

\section{REFERENCES}

Alexander, M. J. L. (2006). "Intrinsic and Imposed Hamstring Length Influence Posterior Pelvic Rotation during Hip Flexion," in Etnická Různost a Občanská Jednota. Editor R. Marada (Brno: Centrum pro studium demokracie a kultury), 49-50. doi:10.1016/s0162-0908(08)70288-5

Bax, M., Goldstein, M., Rosenbaum, P., Leviton, A., Paneth, N., Dan, B., et al. (2005). Proposed Definition and Classification of Cerebral Palsy, April 2005. Dev. Med. Child. Neurol. 47, 571-576. doi:10.1017/ s001216220500112x

Bendová, P., and Fialová, A. (2015). Inclusive Education of Pupils with Special Educational Needs in Czech Republic Primary Schools. Proced. - Soc. Behav. Sci. 171, 812-819. doi:10.1016/j.sbspro.2015.01.196

Braun, V., and Clarke, V. (2006). Using Thematic Analysis in Psychology. Qual. Res. Psychol. 3 (2), 77-101. Available at: https://core.ac.uk/download/pdf/ 1347976.pdf. (Accessed October 13, 2020). doi:10.1191/1478088706qp063oa

Burke, M. M., and Sandman, L. (2015). In the Voices of Parents. Res. Pract. Persons Severe Disabilities 40 (1), 71-85. doi:10.1177/1540796915585109

Cavet, J. (2000). Research Section: 'It's a Delicate Thing': Coping with a Hidden Disability in Mainstream Schools. Br. J. Spec. Educ. 27 (3), 154-159. doi:10.1111/1467-8527.00179

Cologon, K. (2020). Is Inclusive Education Really for Everyone? Family Stories of Children and Young People Labelled with 'Severe and Multiple' or 'Profound' 'Disabilities'. Res. Pap. Educ. 35, 1-23. doi:10.1080/02671522.2020.1849372

Colver, A., Rapp, M., Eisemann, N., Ehlinger, V., Thyen, U., Dickinson, H. O., et al. (2015). Self-Reported Quality of Life of Adolescents with Cerebral Palsy: A Cross-Sectional and Longitudinal Analysis. Lancet 385, 705-716. doi:10.1016/ S0140-6736(14)61229-0

Cook, A., Ogden, J., and Winstone, N. (2016). The Experiences of Learning, friendship and Bullying of Boys with Autism in Mainstream and Special
April 2, 2019, with respect to the Directive of the Dean of the Faculty of Education UP, 3S/2015. Written informed consent to participate in this study was provided by the participants' legal guardian/next of kin. Written informed consent was obtained from the individual(s), and minor(s)' legal guardian/next of kin, for the publication of any potentially identifiable images or data included in this article.

\section{AUTHOR CONTRIBUTIONS}

DS: This project was based on our mutual cooperation, I preprepared materials for the interviews and contacted the participants, provided them information and interviewed them. Then I transcribed verbatim and shared with co-author. We compared and discussed our analyses and results and this text is the result of our cooperation. JK: My co-author participated in thematic analyses and processing results, cooperated on the article writing, mainly on the theoretical background, discussion and conclusion. We discussed everything continuously.

\section{FUNDING}

This research was supported by the project "Research of inclusion in people with special needs", project number: IGA_PdF_2021_024.

Settings: a Qualitative Study. Br. J. Spec. Educ. 43 (3), 250-271. doi:10.1111/ 1467-8578.12143

De Villiers, A. J. (2015). Stories of School Reintegration Following Traumatic Brain Injury (TBI): The Experiences of Children, Their Primary Caregivers and Educators in the Western Cape. Thesis. Cape Town: University of Cape Town. Available at: http://hdl.handle.net/11427/15500. (Accessed April 9, 2020).

Filipová, D. (2002). Projektujeme Bez Bariér. 1st ed. Prague: MPSV ČR.

Forteza, D., Fuster, L., and Moreno-Tallón, F. (2019). Barreras para el Aprendizaje y la Participación en la Escuela del Alumnado con Dislexia: Voces de Familias. Revista Internacional de Educación para la Justicia Soc. 8 (2), 113-130. doi:10.15366/riejs2019.8.2.006

Gavora, P. (2000). Úvod Do Pedagogického Výzkumu. Brno: Paido.

Gray, C. (2005). Inclusion, Impact and Need: Young Children with a Visual Impairment. Child. Care Pract. 11 (2), 179-190. doi:10.1080/13575270500053126

Grove, K. A., and Fisher, D. (1999). Entrepreneurs of Meaning. Remedial Spec. Educ. 20 (4), 208-215. doi:10.1177/074193259902000404

Habart, T. (2010). Krok Za Krokem K Inkluzi. Praha: Člověk v tísni.

Hasan, M., and Islam, T. (2020). Achieving Functional Independence of Children with Cerebral Palsy at the Mainstream School: An Overview. Open Access Libr. J. 7, 1-23. doi:10.4236/oalib.1106597

Hronová, Z. (2020). Inkluze Je Opředena Mýty, Svádí Se Na Ni Všechny Problémy Školství, Říká Odbornice. EDUin Informační centrum o vzdělávání. Available at: https://www.eduin.cz/clanky/aktualne-cz-inkluze-je-opredena-myty-svadise-na-ni-vsechny-problemy-skolstvi/. (Accessed September 4, 2020).

Janoško, P. (2013). Inkluzívna Edukácia. Ružomberok: VERBUM.

Kantor, J., Michali'kova', M., Ludi'kova', L., and Kantorova', Z. (2015). Žité Zkušenosti Rodin Dětí S Těžkým Kombinovaným Postižením. Olomouc: Univerzita Palackého v Olomouci.

Kantorová, L., and Klugar, M. (2020). Czech National Project of Clinical Practice Guidelines Development and its Implementation in Special Education. J. Exceptional People 1 (17), 95-107. Available at: http://www.jep.upol.cz/ 
2020/Journal-of-Exceptional-People-Volume1-Number17.pdf. (Accessed April 9, 2020).

Khairuddin, K. F., and Miles, S. (2020). School Staff Members' and Parents' Experiences of the Inclusion of Deaf Children in Malaysian Mainstream Schools. Education 3-13 48, 273-287. doi:10.1080/03004279.2019.1664403

Kluth, P., Biklen, D., English-Sand, P., and Smukler, D. (2007). Going Away to School. J. Disabil. Pol. Stud. 18 (1), 43-56. doi:10.1177/10442073070180010501

Krastina, E., Berzina, Z., Kraukle, S., and Zake, D. (2006). Inclusion and the Role of Parent Involvement. Transilvanian J. Psychol. 2 (2), 1.

Lederer, B. (2015). Vozíčkáŕi Pátrají. Jen Pětina Škol Je Bez Bariér. Pražský deník.cz. Available at: https://prazsky.denik.cz/zpravy_region/vozickaripatraji-jen-petina-skol-je-bez-barier-20150211.html. (Accessed September 3, 2020).

Lemos, L. (2016). Voices of Adult Latinos with Physical Disabilities and Their Families. PhD. theses. Los Angeles: University of Southern California.

Lilley, R. (2014). Trading Places: Autism Inclusion Disorder and School Change. Int. J. Inclusive Educ. 19 (4), 379-396. doi:10.1080/13603116.2014.935813

Llabrés, J., Muntaner, J. J., and De la Iglesia, B. (2019). Aprender Juntos en la Escuela: Un Derecho Inexcusable y un Beneficio Social. Revista Internacional de Educación para la Justicia Soc. 8 (2), 147-164. doi:10.15366/riejs2019.8.2.008

Majerová, R. (2014). “Lingvistika Ve Speciální Pedagogice," in Terapie Ve Speciápní Pedagogice. Editor O. Müller. 2nd rev (Praha: Grada), 394-399.

Maňák, J., and Švec, V. (2003). Výukové Metody. 1st. Brno: Paido.

Marshall, C., and Rossman, G. B. (2011). Designing Qualitative Research. London: Sage.

Michalík, J. (2015). "Post-ústavní Deinstitucionalizace a Inkluzívní Desegregace," in Perspektivy Speciální Pedagogiky - Potřeby, Možnosti a Výzvy (Olomouc: Univerzita Palackého), 174-180.

Michalík, J. (2011). Zdravotní Postižení a Pomáhajicí Profese. Praha: Portál.

Miller, K. D., Schleien, S. J., White, A. L., and Harrington, L. (2018). "Letting Go:” Parent Perspectives on the Outcomes of an Inclusive Postsecondary Education Experience for Students with Developmental Disabilities. J. Postsecondary Educ. Disabil. 31 (3), 267-285.

Mitchell, D. (2014). What Really Works in Special and Inclusive Education: Using Evidence-Based Teaching Strategies. Second edition. New York: Routledge.

Morelle, M., and Tabane, R. (2019). Challenges Experienced by Learners with Visual Impairments in South African Township Mainstream Primary Schools. S. Afr. J. Educ. 39 (3), 1-6. doi:10.15700/saje.v39n3a1615

Panteliadis, C. P., Hagel, C., Karch, D., and Heinemann, K. (2015). Cerebral Palsy: A Lifelong Challenge Asks for Early Intervention. Open Neurol. J. 9, 45-52. doi:10.2174/1874205X01509010045

Přibáň, J. (1997). Hranice Práva a Tolerance. Prague: Sociologické nakladatelství.

Rachmadani, F., Murtiningsih, S., and Maharani, S. D. (2021). Inclusive Education for Children with Cerebral Palsy: A Comment on Dilemma Incoherence between Policy and Practice. Int. J. Learn. Teach. 7 (2), 82-89. doi:10.18178/ ijlt.7.2.82-89

Rogers, C. (2007). Experiencing an 'inclusive' Education: Parents and Their Children with 'special Educational Needs'. Br. J. Sociol. Educ. 28 (1), 55-68. doi:10.1080/01425690600996659

Rokeach, M. (1973). The Nature of Human Values. New York: Free Press.

Ryndak, D. L., Taub, D., Jorgensen, C. M., Gonsier-Gerdin, J., Arndt, K., Sauer, J., et al. (2014). Policy and the Impact on Placement, Involvement, and Progress in General Education: Critical Issues that Require Rectification. Res. Pract. Persons Severe Disabilities 39, 65-74. doi:10.1177/1540796914533942

Sak, P., and Saková, K. (2004). Mládež Na Křižovatce. 1st. Prague: Svoboda Servis.
Sedláčková, D. (2018a). Students with Physical Disabilities and Their Experience with Inclusive Education: Literature Review. Int. Multidisciplinary Scientific Conf. Soc. Sci. 5 (3.5), 673-680. Albena: SGEM. doi:10.5593/sgemsocial2018/3.5

Sedláčková, D. (2018b). Students with Physical Disabilities and Their Experience with Inclusive Education:Review of Czech Sources. Int. Multidisciplinary Scientific Conf. Soc. Sci. 5 (3.5), 681-688. Albena: SGEM. doi:10.5593/ sgemsocial2018/3.5

Sentenac, M., Ehlinger, V., Michelsen, S. I., Marcelli, M., Dickinson, H. O., and Arnaud, C. (2013). Determinants of Inclusive Education of 8-12 Year-Old Children with Cerebral Palsy in 9 European Regions. Res. Dev. Disabil. 34 (1), 588-595. doi:10.1016/j.ridd.2012.09.019

Svoboda, M., Krejčírová, D., and Vágnerová, M. (2015). Psychodiagnostika Dětí a Dospivajicích. Vydání třetí. Praha: Portál.

Tesařová, M. (2016). Jak Na Žáky: Zvládání Náročných Situací Ve Třídè. Prague: Portál.

Tran, K. V. (2014). Exploring the Experience of Children with Disabilities at School Settings in Vietnam Context. SpringerPlus 3 (1), 103. doi:10.1186/2193-18013-103

UNESCO (1994). Final reportWorld Conference on Special Needs Education: Access and Quality. Paris: UNESCO. Available at: https://eric.ed.gov/?id=ED384189. (Accessed September 3, 2020).

Vágnerová, M. (2004). Psychopatologie Pro Pomáhající Profese. 3rd ext. Prague: Portál.

Vágnerová, M. (2000). Vývojová Psychologie: Dètství, Dospělost, Stárí. Prague: Portál.

Van Manen, M. (1997). Researching Lived Experience: Human Science for the Action Sensitive Pedagogy. 2nd ed. London: The Althouse Press.

Van Manen, M. (2016). Researching Lived Experience: Human Science for an Action Sensitive Pedagogy. 2nd ed. New York, NY: Rutledge.

Vítková, M. (2006). Somatopedické Aspekty. 2nd ed. Brno: Paido.

Watier, L. (2016). Ubylo Žáků Se Zdravotním Postižením. Statistika \& my. Available at: http://statistikaamy.cz/2016/05/ubylo-zaku-se-zdravotnimpostizenim. (Accessed October 13, 2019).

Webster, A., and Roberts, J. (2020). Implementing the School-Wide Autism Competency Model to Improve Outcomes for Students on the Autism Spectrum: A Multiple Case Study of Three Schools. Int. J. Inclusive Educ. 24, 1-19. doi:10.1080/13603116.2020.1735540

Wilhelm, M., Bintinger, G., and Eichelberger, H. (2002). Eine Schule fur dich und mich. Inklusiven Unterricht und inklusive Schule gestalten. Wien: Studienverlag.

Conflict of Interest: The authors declare that the research was conducted in the absence of any commercial or financial relationships that could be construed as a potential conflict of interest.

Publisher's Note: All claims expressed in this article are solely those of the authors and do not necessarily represent those of their affiliated organizations, or those of the publisher, the editors and the reviewers. Any product that may be evaluated in this article, or claim that may be made by its manufacturer, is not guaranteed or endorsed by the publisher.

Copyright (0 2022 Sedláčková and Kantor. This is an open-access article distributed under the terms of the Creative Commons Attribution License (CC BY). The use, distribution or reproduction in other forums is permitted, provided the original author $(s)$ and the copyright owner(s) are credited and that the original publication in this journal is cited, in accordance with accepted academic practice. No use, distribution or reproduction is permitted which does not comply with these terms. 